\title{
Developing Leadership for Increasing Complexity: A Review of Online Graduate Leadership Programs
}

\author{
Steven L. Winton Ph.D. \\ Program Director/ Assistant Professor \\ MA Leadership and Organizational Development \\ Saint Louis University \\ Sarah Palmer M.S. \\ Saint Louis University \\ Patrick J. Hughes Ph.D. \\ Program Director/ Assistant Professor \\ Justice Leadership and Management \\ University of Baltimore
}

\begin{abstract}
Leadership education must evolve to keep pace with the growing recognition that effective leadership happens in a complex environment and is as much a systemic variable as a personal one. As part of a program review process, a graduate leadership program at a private Midwestern university conducted a qualitative review of 18 online graduate programs in leadership education. In the absence of a discipline or accrediting body to govern leadership degree programs, we utilized the integrating framework of complexity leadership theory (CLT), as well as two professional societies, to understand how the curricula and competencies of online graduate education align and diverge to meet the changing assumptions and challenges of leadership.
\end{abstract}

\section{Introduction}

Leadership in the twenty-first century will not be constrained within traditional organizational boundaries. As hierarchies flatten, and boundaries blur, leadership will become increasingly dynamic - emerging throughout and across organizations (Lichtenstein, Uhl-Bien, Marion, Seers, Orton \& Schreiber, 2006; Osborn, Hunt \& Jauch, 2002; Schneider \& Somers, 2006). Leadership that is increasingly embedded within the organizational fabric, to effectively thrive in change, must be adept at building organizational capacity through continuous learning and innovation. This has implications for the leadership competencies taught and practiced (Shoup, 2016).

In this brief, we examine if online graduate leadership programs are providing graduate students with comparable foundations in the field of leadership, specifically as it relates to the competencies necessary to be effective in complex adaptive systems (CAS). Brungardt, Greenleaf, Brungardt, and Arensdorf (2006) provided a qualitative review of 15 undergraduate leadership degree programs, examining elements such as the school profile, the mission and 
purpose of the program, and the curricula. These researchers found several inconsistencies among programs, specifically in terms of curricula and focus. At the end of their review, these authors recommended that leadership educators increase collaboration among programs in order to establish a "cohesive framework...to unify our efforts" (p. 22).

We want to further explore this recommendation to advance our understanding of leadership education at the graduate level, specifically within an online learning environment. Our goals for this brief are: 1) to examine the competencies and curricula of online graduate programs against the unifying framework of complexity leadership theory (CLT), and 2) to spur dialog concerning the standardization of graduate leadership education and whether or not best practices can or should exist, particularly given the lack of a "leadership" discipline.

Complexity Leadership Theory. Curricula in degree programs, particularly those within a recognized academic discipline, typically contain a set of competencies that are consistent across programs. In rapidly changing or emerging disciplines, however, it is not uncommon to see vast differences among curricula. Applied to leadership degree programs, Shoup (2016) suggests the need for one theoretical, systemic approach and advocates CLT as a framework to further strengthen the position of leadership as its own discipline. Further, because CLT does not prescribe to one particular technical application, or theory of leadership, it offers a compelling holistic framework for understanding the competencies necessary for tomorrow's leaders.

Uhl-Bien, Marion, and McKelvey (2007) define CLT as "focusing on identifying and exploring the strategies and behaviors that foster organizational and subunit creativity, learning, and adaptability when appropriate CAS dynamics are enabled within contexts of hierarchical coordination" (p.299). Weberg (2013) argued that this necessitates a paradigm shift from a leader-centric focus to one where leadership is viewed as "a dynamic relationship between culture, followers, self, and organization..." (p. 13). Keene (2000) suggested that the interplay between these various elements (i.e., with each other and the environment) is an important parameter of CAS. As these various factors change unpredictably, leaders must be able to handle the lack of control in their environments. CLT, characterized by the concept of "emergent leadership" (p. 17), posits that leaders need to engage in behaviors that build an organization's capacity to innovate, learn, and change (Weberg, 2013). We believe graduate leadership programs should address this need and challenge the assumptions of traditional leadership perspectives, as the demand for adaptive and innovative leadership increases.

Uhl-Bien et al. (2007) identified, within CLT, three types of leadership needed within the modern organization: administrative, adaptive, and enabling. They describe administrative leadership as managerial in nature and primarily focused on reaching outcomes through efficiency; consequently, these competencies, albeit still critical, reside more in yesterday's, hierarchical organization. Adaptive and enabling leadership, on the contrary, recognize that leadership emerges through the interactions of individuals, and suggest that the role of leadership is to create optimal organizational situations that foster innovation, flexibility, and organizational learning. We see enabling and adaptive leadership as most germane to future graduate leadership development. Although far from an exhaustive list, we build on the work of Uhl-Bien et al. 
(2007) to highlight broad leadership competencies important for graduate leadership education as it pertains to CLT, particularly those related to change within CAS:

Table 1. Competencies related to CLT

\section{Administrative}

\section{Adaptive}

Enabling

Strategic Thinking - being able to develop a vision and strategy, as well as see how all of the different elements within the system interrelate (Fairholm, 2009; Uhl-Bien \& Marion, 2009). Although Uhl-Bien et al. (2007) suggest strategy to be primarily administrative, we broaden this competency to include Fairholm's (2009) concept of strategic-thinking, which involves leadership that embraces chaos and ambiguity.
Continuous Improvement and Operational Efficiency being able to plan and coordinate for efficiency and continual improvement (Shoup, 2016).
Organizational Culture - understanding how the culture impacts members of the organization, its interactions with external environment, etc., as well as being able to effectively navigate it. Shoup (2016) stresses the importance of the formal organization, but also claims the need for leaders to focus on the organizational culture, informal rules and norms.
Creative Problem-Solving and Conflict Management being able to create solutions when faced with a situation or conflict within the organization (Uhl-Bien \& Marion, 2009; Uhl-Bien et al., 2007)

Innovation and
Organizational Learning -
being able to create new
solutions within a changing
environment (Uhl-Bien \&
Marion, 2009). This is very
much related to Yukl's (2009)
reflection on ways leadership
can enhance organizational
learning.

\section{Innovation and} Organizational Learning being able to create new solutions within a changing environment (Uhl-Bien \& Marion, 2009). This is very much related to Yukl's (2009) reflection on ways leadership learning.

Research, Evidence-Based Decision Making and Ethics - being able to effectively analyze a situation, make decisions informed by sound evidence/data, and apply ethical principles. Shoup (2016) suggests an organization legitimizes and sustains itself through strong implementation of values. We see this as a foundational set of competencies integral to all categories of CLT.

*Dotted lines represent Uhl-Bien \& Marion's (2009) concept of "entanglement" across and within formal structures and the highly interrelated nature of these competencies within a CAS

The Online Learning Environment. Higher education is also not immune to change. As noted by Pederson (2015), education at every level is changing, and traditional institutional systems may no longer be able to keep pace with the continuous advances learners require. Further, Pederson noted that there is a trend of employees continuing to learn throughout their careers, which often translates to pursuing a graduate or some type of professional degree in an environment that is conducive to the needs of the working population. According to a 2010 
report from the Commission on the Future of Graduate Education in the United States, the number of "non-traditional" students has consistently grown, with an increase in the number of students who are 40 years or older in graduate programs (Wendler et al., 2010).

Taylor (2015) indicated that while the number of non-traditional students is increasing, the barriers that these students face are also abundant. To elaborate, these students often have a number of competing responsibilities in addition to their education (e.g., full or part time jobs; children). Thus, graduate programs that make it possible for non-traditional students to be successful (e.g., online learning) are essential. Ross-Gordon (2011) suggested that nontraditional students are "here to stay" (p. 29), subsequently requiring the design and delivery of programs to be more responsive to the lifestyles of this population.

As part of a program review process, we reviewed graduate programs that offered either a fully online or "blended" (i.e., online and some in-person courses) delivery method and identified a number of both private and public institutions with leadership programs. In selecting graduate programs to include in this exploratory qualitative study, the following criteria were used: A) the program must be at the graduate-level, B) courses must be delivered in an online or blended format, and $\mathrm{C}$ ) information must be available regarding the competencies/curricula of the program. Using these guidelines, 18 programs were reviewed against the backdrop of CLT. 
Table 2. Institutions reviewed.

\begin{tabular}{|c|c|c|c|}
\hline University/College & $\begin{array}{c}\text { College or } \\
\text { School Name }\end{array}$ & Degree & Capstone Requirement \\
\hline $\begin{array}{l}\text { Austin Peay State } \\
\text { University }\end{array}$ & $\begin{array}{l}\text { Center for Adult } \\
\text { and Professional } \\
\text { Studies }\end{array}$ & $\begin{array}{l}\text { Master of Professional } \\
\text { Studies - Concentration for } \\
\text { Strategic Leadership ( } 33 \\
\text { Hours) }\end{array}$ & Professional project \\
\hline $\begin{array}{l}\text { Azusa Pacific } \\
\text { University }\end{array}$ & * & $\begin{array}{l}\text { Master of Arts in } \\
\text { Leadership and } \\
\text { Organizational Studies (33 } \\
\text { Hours) }\end{array}$ & * \\
\hline $\begin{array}{l}\text { Black Hills State } \\
\text { University }\end{array}$ & $\begin{array}{l}\text { Online/ } \\
\text { Distance } \\
\text { Learning }\end{array}$ & $\begin{array}{l}\text { Master of Science in } \\
\text { Strategic Leadership ( } 33 \\
\text { Hours) }\end{array}$ & Practicum \\
\hline $\begin{array}{l}\text { Colorado State } \\
\text { University }\end{array}$ & $\begin{array}{l}\text { CSU-Global } \\
\text { Campus }\end{array}$ & $\begin{array}{l}\text { Master of Science in } \\
\text { Organizational Leadership } \\
\text { (36 Hours) }\end{array}$ & $\begin{array}{l}\text { Capstone course or } \\
\text { Management: Strategy } \\
\text { and Execution Course }\end{array}$ \\
\hline $\begin{array}{l}\text { Colorado } \\
\text { Technical } \\
\text { University }\end{array}$ & $\begin{array}{l}\text { Online } \\
\text { Master's } \\
\text { Degree } \\
\text { Programs }\end{array}$ & $\begin{array}{l}\text { Master of Science in } \\
\text { Management - } \\
\text { Organizational Leadership } \\
\text { and Change ( } 48 \text { Hours) }\end{array}$ & $\begin{array}{l}\text { Management Research } \\
\text { Practicum }\end{array}$ \\
\hline $\begin{array}{l}\text { Creighton } \\
\text { University }\end{array}$ & $\begin{array}{l}\text { College of } \\
\text { Professional } \\
\text { Studies }\end{array}$ & $\begin{array}{l}\text { Master of Science in } \\
\text { Leadership ( } 36 \text { Hours) }\end{array}$ & Project-based Capstone \\
\hline $\begin{array}{l}\text { The George } \\
\text { Washington } \\
\text { University }\end{array}$ & $\begin{array}{l}\text { College of } \\
\text { Professional } \\
\text { Studies }\end{array}$ & $\begin{array}{l}\text { Masters of Professional } \\
\text { Studies in Public } \\
\text { Leadership }\end{array}$ & $\begin{array}{l}\text { Performance } \\
\text { Improvement Research } \\
\text { Project }\end{array}$ \\
\hline $\begin{array}{l}\text { Gonzaga } \\
\text { University }\end{array}$ & $\begin{array}{l}\text { School of } \\
\text { Professional } \\
\text { Studies }\end{array}$ & $\begin{array}{l}\text { Master of Arts in } \\
\text { Organizational Leadership } \\
\text { (30 Hours) }\end{array}$ & $\begin{array}{l}\text { 3-day Leadership and } \\
\text { Hardiness Immersion }\end{array}$ \\
\hline Lewis University & & $\begin{array}{l}\text { Master of Arts in } \\
\text { Organizational Leadership } \\
\text { (36 Hours) }\end{array}$ & $\begin{array}{l}\text { Capstone Course: } \\
\text { Leadership and the } \\
\text { Future }\end{array}$ \\
\hline $\begin{array}{l}\text { Marquette } \\
\text { University }\end{array}$ & $\begin{array}{l}\text { College of } \\
\text { Professional } \\
\text { Studies }\end{array}$ & $\begin{array}{l}\text { Master of Arts in } \\
\text { Leadership Studies (36 } \\
\text { Hours) }\end{array}$ & * \\
\hline
\end{tabular}




\begin{tabular}{|c|c|c|c|}
\hline $\begin{array}{l}\text { Northeastern } \\
\text { University }\end{array}$ & $\begin{array}{l}\text { College of } \\
\text { Professional } \\
\text { Studies }\end{array}$ & $\begin{array}{l}\text { Master of Science in } \\
\text { Leadership ( } 45 \text { Hours) }\end{array}$ & $\begin{array}{l}\text { Capstone - case study } \\
\text { and case analysis }\end{array}$ \\
\hline $\begin{array}{l}\text { Pennsylvania } \\
\text { State University }\end{array}$ & $\begin{array}{l}\text { Penn State } \\
\text { World Campus }\end{array}$ & $\begin{array}{l}\text { Master of Professional } \\
\text { Studies in the Psychology } \\
\text { of Leadership at Work ( } 33 \\
\text { Hours) }\end{array}$ & Capstone experience \\
\hline $\begin{array}{l}\text { Quinnipiac } \\
\text { University }\end{array}$ & $\begin{array}{l}\text { Quinnipiac } \\
\text { University } \\
\text { Online }\end{array}$ & $\begin{array}{l}\text { Master of Science in } \\
\text { Organizational Leadership } \\
\text { (33 Hours) }\end{array}$ & $\begin{array}{l}\text { Leadership Consulting } \\
\text { Capstone }\end{array}$ \\
\hline $\begin{array}{l}\text { Saint Louis } \\
\text { University }\end{array}$ & $\begin{array}{l}\text { School for } \\
\text { Professional } \\
\text { Studies }\end{array}$ & $\begin{array}{l}\text { Master of Arts in } \\
\text { Leadership and } \\
\text { Organizational } \\
\text { Development ( } 36 \text { Hours) }\end{array}$ & Action Research I \& II \\
\hline $\begin{array}{l}\text { Saint Mary's } \\
\text { University of } \\
\text { Minnesota }\end{array}$ & Online Programs & $\begin{array}{l}\text { Master of Arts in } \\
\text { Organizational Leadership } \\
\text { (36 Hours) }\end{array}$ & $\begin{array}{l}\text { Organizational } \\
\text { Leadership Capstone }\end{array}$ \\
\hline $\begin{array}{l}\text { Tennessee Tech } \\
\text { University }\end{array}$ & $\begin{array}{l}\text { School of } \\
\text { Professional } \\
\text { Studies }\end{array}$ & $\begin{array}{l}\text { Master of Professional } \\
\text { Studies - Concentrations in } \\
\text { HR Leadership, Strategic } \\
\text { Leadership ( } 33 \text { Hours) }\end{array}$ & $\begin{array}{l}\text { Culminating Professional } \\
\text { Project }\end{array}$ \\
\hline $\begin{array}{l}\text { University of } \\
\text { Wisconsin - } \\
\text { Platteville }\end{array}$ & $\begin{array}{l}\text { Distance } \\
\text { Education }\end{array}$ & $\begin{array}{l}\text { Master of Science in } \\
\text { Organizational Change } \\
\text { Leadership ( } 30 \text { Hours) }\end{array}$ & $\begin{array}{l}\text { Capstone, seminar paper } \\
\text { research, or thesis } \\
\text { research }\end{array}$ \\
\hline $\begin{array}{l}\text { University of } \\
\text { South Dakota }\end{array}$ & Online Programs & $\begin{array}{l}\text { Master of Science in } \\
\text { Administration - } \\
\text { Organizational Leadership } \\
\text { (36 Hours) }\end{array}$ & Capstone Project \\
\hline
\end{tabular}

*Information was not available on website

In order to examine how the competencies and curricula of these graduate programs align with one another, as well as with professional society standards, the following data were collected: program competencies/learning outcomes, course information, and required research components. A list of the competencies or learning outcomes from 10 of the 18 universities (i.e., 8 programs did not have outcomes/competencies readily available on the website) are provided in Table 3. We utilized a hybrid coding approach to derive program competency and curricula themes. After conducting an initial round of open coding, we collapsed the codes into larger themes. We then contrasted these themes against CLT to further refine our list. We identified the 
following six major themes: change, culture, strategy/strategic thinking, ethics, research, and conflict/conflict resolution.

Table 3. Competencies, learning outcomes, and objectives.

University/College

Colorado State University

\section{Competencies, Learning Outcomes, and Objectives}

1. Analyze how individuals and groups interact within organizations.

2. Develop knowledge of strategies that support stakeholders and enhance organizational capacity.

3. Evaluate human behavior within organizations to understand effective leadership, organizational communication, ethical practices, and cogent decision-making principles.

4. Demonstrate the ability to create and sustain lifelong learning to promote a cohesive culture within an organization.

5. Assess current challenges of organizational leadership in historical and current contexts.

6. Analyze and integrate theories of leadership within personal and professional contexts.

7. Demonstrate skills for effective strategy development within an organization by completing a capstone project.

Colorado

Technical

University
1. Evaluate the appropriate leadership and management actions needed across disciplines and in various global environments.

2. Synthesize theory and practice in day-to-day managerial decision making and organizational change

3. Apply appropriate strategic, technical, operational, and ethical principles to solve organizational challenges and meet organizational goals and objectives
1. To innovate, adapt and act in a changing world

2. To make data-driven and strategic decisions

3. To manage and evaluate projects and portfolios

4. To communicate effectively across different organizations and stakeholders

5. To use practical reasoning, cross functional teams and teamwork to solve complex problems

6. To identify talent, mentor, network and plan for succession

7. To use influence and persuasive techniques during conditions of high uncertainty and in crisis

8. To lead across international borders and cultures

9. To predict high-performing employees and ways to retain them

10. To manage conflict and facilitate group processes 


\section{The George Washington University}

1. Understand the roles and responsibilities of the public, private, and social sectors of society

2. Analyze the challenges faced by leaders of organizations working in a multi-sector environment

3. Apply best practices from across the sectors to resolve organizational issues and problems

4. Results Based-Management

1. Understand various management systems focused on achieving high performance in organizations

2. Apply a framework for managing the multi-sector workforce in their organization

3. Demonstrate the application of performance-based financial management for planning and resourcing public organizations

4. Organizational Performance Improvement

1. Understand various methodologies for improving organizational performance

2. Analyze current organizational processes from design to implementation

3. Create and implement a process improvement project for an organization

$\begin{array}{ll}\text { Gonzaga University } & \text { 1. Align others around a shared vision } \\ \text { 2. Lead change, empower self, and others } \\ \text { 3. Analyze and apply models for leading organizational change } \\ \text { 4. Apply decision-making models in interpersonal, group, and } \\ \text { organizational conflict }\end{array}$


4. Apply theory and principles of group dynamics in assuming multiple group roles and responsibilities.

5. Apply quantitative and qualitative research methods encompassing scholarly writing as related to leadership practice and the selected specialization, if applicable.

\section{Northeastern University}

1. Develop and bolster your leadership competencies

2. Explore key leadership areas such as: management, ethics, strategic thinking, and organizational culture

3. Prepare for the challenges and opportunities associated with leading in a global world

4. Exercise leadership skills through action-learning and research projects

5. Improve your ability to lead and work both independently and collaboratively

\section{Saint Louis University}

1. Coaching and mentoring to assist in employee development

2. Strategic visioning, with an emphasis on future-focused leadership

3. Evidence-based decision making

4. Leverage current leadership competencies and manage future leadership development

5. Integrate project management logistical needs with interpersonal leadership needs

6. Lead change initiative efforts in an organization
1. Interpret the contexts and environments in which organizations operate.

2. Integrate and apply analytical principles and skills to make complex strategic decisions.

3. Develop individual awareness, style, and communication skills that influence managerial outcomes.

4. Collaborate in complex work teams utilizing effective motivational and coaching techniques.

5. Develop and integrate creative, adaptive strategies that promote positive change and innovation.

6. Evaluate the ethical and legal implications of one's actions.

7. Conduct research and communicate results successfully.

8. Create an organizational culture of diversity and inclusion.

9. Activate self-directed strategies for continued personal and professional learning.

\footnotetext{
*8 of the programs examined did not have information available on their websites
} 
In ten of the programs reviewed, the concept of change was found in either the program's competencies or curriculum. For example, some competencies included: driving positive change in any business, strategizing the change process, monitoring the impact of change in an organization (plus group and individual reactions to change), and leadership in organizational change. Several institutions offered courses related to change (e.g., Leading Innovation and Adaptive Change). In relation to CLT, the competency of change parallels closely with the need for leadership to be innovative and create new solutions within a changing environment. As noted by Keene (2000), leaders will continue to be faced with an increasing pace of change and must be equipped with the necessary skills to not simply "control" changes within the organization and external environment, but to accept that uncertainty is an inevitable characteristic of organizational life. The CLT competency of innovation is met within leadership programs that are providing students with a foundation to monitor and lead change within their organizations.

The second major theme that was uncovered was the concept of organizational culture. In six of the programs reviewed, culture was mentioned in either the competencies or curriculum. For example, programs described competencies such as shape organizational culture with a particular emphasis on diversity, diagnose and address structural and cultural programs, explore key leadership areas of organizational culture, lead across international borders and cultures, and create an organizational culture of diversity and inclusion. An example of a courses included within these programs is Leadership for a Diverse World. As noted earlier, Weberg (2013) described CLT as a way to understand how leadership and culture influence one another in a dynamic manner, subsequently making it difficult to disentangle the two. In this new framework, leaders must be able to both analyze organizational culture and engage in the necessary behaviors to create positive and cohesive cultures.

The next theme that was found in seven of the programs reviewed was the concept of implementing strategy or strategic thinking. Specifically, various programs indicated that students should be able to make data-driven and strategic decisions, implement strategic initiatives in order to maintain a competitive advantage, demonstrate skills for effective strategy development, strategize the change process through organizational and individual tactical approaches, as well as have a broad understanding of strategy pertaining to organizational leadership. Some programs offered courses in Strategy and Planning and Organizational Leadership: Strategy and Execution.

Fourth, the concept of ethics was a prominent theme in several of the graduate programs. Specifically, in 7 of the programs, there was a mention of ethics in the competencies or objectives of the program. Some examples include: identify ethical issues and apply ethical principles, values, theories or frameworks to leadership practice, identify and assess the nature of ethical issues in organizations, assess the congruence between personal norms and ethical principles, and develop real-life methods of practicing ethical conduct. In terms of curricula, some courses offered include Ethical Leadership and Leadership and Ethical Decision-Making.

A fifth major theme in the competencies and curricula was conflict. To elaborate, many of these programs expect that students will be able to apply decision-making models in interpersonal, group, and organizational conflict, acquire skills for conflict management, manage 
conflict and facilitate group processes, and diagnose and propose methods to resolve conflict. Some universities offered courses on Conflict Management and Negotiation and Conflict Resolution. This theme relates closely to Uhl-Bien et al.'s (2007) description of a leader within the CLT framework as one who is able to creatively problem solve, and generate a new understanding of issues.

Finally, many schools indicated that students should be able to apply quantitative and qualitative research methods encompassing scholarly writing as related to leadership practice, exercise leadership skills through action-learning and research projects, synthesize the knowledge they gain in order to analyze and evaluate a current organizational challenge and propose solutions for increased effectiveness, as well as conduct research and communicate results successfully. Specific courses that reflect the theme of research methodology that some programs offer include Applied Quantitative Methods in Leadership Studies, Workplace Research: Critical Thinking and Decision-Making, and Research in Organizations.

In considering these six major themes extracted from the competencies and curricula of the graduate leadership programs, there does appear to be notable overlap among institutions. Generally, when examining each theme individually, around half of the programs reviewed had some alignment in competencies or course offerings. While finding this overlap between programs does provide some evidence that programs across the United States are generally using similar frameworks in graduate leadership education, it is equally important that these competencies are consistent with professional society standards.

Two professional societies were reviewed that have provided competencies in the leadership domain: Society for Human Resource Management (SHRM) and the U.S. Office of Personnel Management. For the discipline of leadership, SHRM describes competencies at both a "global" level (7 total), as well as having a list of "essential" leadership competencies (20 total). In viewing SHRM's essential competencies, a leader should be able to lead the organization, self, and others in a number of ways, such as managing and solving problems (similar to the theme of conflict from the graduate program review), setting vision and strategy (similar to strategy), valuing diversity and difference (similar to ethics and culture), and developing adaptability, managing change, and taking risks and innovating (similar to change). Surprisingly, there does not seem to be an essential leadership competency from SHRM that is explicitly related to the research methodology theme (e.g., synthesizing knowledge, actionlearning, conducting research) found within the graduate programs. Thus, there seemed to be strong alignment between SHRM's list of leadership competencies and those found across the graduate programs.

The U.S. Office of Personnel Management (OPM) also provides several competencies for leadership, suggesting that employers are looking for competencies such as technical credibility, flexibility, and oral and written communication, all which are notably missing from the SHRM competencies. In addition, OPM goes beyond the traditional areas of leading others and leading the organization, for example, and adds competencies such as business acumen (e.g., financial and human capital management) and the ability to build coalitions (e.g., political savvy, partnering). In reviewing the competencies and curricula from the 18 graduate programs, areas such as financial management and political savviness do not appear to be a priority. 
Beyond the competencies and coursework that was examined in the review of graduate leadership programs, another area that was of particular interest was the research component of these programs (See Table 2). The number of research credit hours required from these various institutions was quite standardized across the board. Specifically, each program required approximately three credit hours involving some sort of capstone or research project. This finding is particularly interesting, as it was the most consistent "element" of online graduate leadership education found in the review, which may suggest some type of research component analyzing real organizational issues is a "best practice" in this field.

\section{Discussion}

As noted in the beginning of this brief, the two primary purposes of reviewing these leadership programs were to examine their alignment (and gaps) and to spur dialog regarding the various leadership education frameworks. We wanted to explore what elements of these programs may be considered "best practice" in light of a leadership framework that stresses the complexity of the modern organization (CLT).

In terms of the first contribution, leaders of these graduate programs may use this review as a benchmark to see how their program compares to other similar programs (e.g., Does our program highlight the major themes found in the other programs? Do we have similar competencies? Do we require a standard research component in our program?). Our small sample suggests that while online graduate programs align closely with one another in terms of curricula and research components, there are some gaps between professional society standards and these programs (e.g., competencies focused on research are notably missing from society standards, while competencies pertaining to business acumen, for example, are absent from graduate programs); however, it should be reiterated that these benchmarks were not specifically developed for graduate leadership education.

In relation to CLT, there does appear to be standardization across programs in terms of providing students with courses that will prepare them for unpredictable and changing environments as leaders. While there are certainly traces of the more traditional framework of leadership (e.g., administrative) within these programs, it is evident that all include some aspects of leadership that emphasize dealing with the increasingly complex world. Thus, in terms of the second implication of this review, we believe this preliminary research will indeed spur conversation regarding the changing nature of leadership and how it is reflected in graduate leadership education. We provided some initial evidence to suggest that online graduate leadership is moving beyond a leader-centric perspective to one that requires a systemic, innovative approach to respond to changes at all levels of an organization.

Through our review, our goal was to provide a starting point, through the lens of an integrating framework (i.e., CLT), that supports the possible creation of standard competencies for leadership programs. In addition, consistent with the National Leadership Education Research Agenda (NLERA), we hope this review serves as an impetus for subsequent research efforts aimed toward the creation of accrediting standards for graduate leadership programs and to solidify "leadership" as its own discipline. 
Future Research and Limitations. While we contend that this review provides a preliminary overview of graduate leadership education, there are a number of ways this research should be extended. First, in this review, we solely looked at a small sample of graduate programs operating in an online or blended environment. In the future, including a larger sample of programs housed in a traditional setting (i.e., physically in a classroom) will be important to examine how these programs align with virtual programs. Other research may seek to compare leadership programs residing in different departments (e.g., business, education, political science, and professional studies).

Future research should also consider a more thorough examination of not only the competencies taught, but how they are taught. A more in-depth understanding of leadership pedagogy is especially critical given the disruption in higher education. We suggest research aimed toward understanding how leadership programs utilizing these newer modalities of learning facilitate the application of leadership competencies. For example, there is an opportunity to analyze how various leadership program capstones are having students synthesize and apply the competencies learned throughout their graduate learning experience. Similarly, it would be beneficial to examine the unique ways in which online leadership education is facilitating peer learning and reflection for self-awareness. Finally, we foresee a more robust theoretical argument around the future of leadership education given the constant change and complexity of the world. For example, what are the implications for a discipline of leadership, or a universal set of competencies, when much of leadership is considered contextual and emergent? 


\section{References}

Brungardt, C., Greenleaf, J., Brungardt, C., \& Arensdorf, J. (2006). Majoring in leadership: A review of undergraduate leadership degree programs. Journal of Leadership Education, $5(1), 4-25$.

Fairholm, M. R. (2009). Leadership and organizational strategy. The Innovation Journal: The Public Sector Innovation Journal, 14(1), 1-16.

Keene, A. (2000). Complexity theory: The changing role of leadership. Industrial and Commercial Training, 32(1), 15-18.

Lichtenstein, B. B., Uhl-Bien, M., Marion, R., Seers, A., Orton, J. D., \& Schreiber, C. (2006). Complexity leadership theory: An interactive perspective on leading in complex adaptive systems.

Osborn, R. N., Hunt, J. G., \& Jauch, L. R. (2002). Toward a contextual theory of leadership. The Leadership Quarterly, 13(6), 797-837.

Pedersen, K. (2015). Keeping pace with the changing face of higher ed. Online Learning Consortium. Retrieved April 23, 2017 from: http://onlinelearningconsortium.org/changing-university/

Ross-Gordon, J. M. (2011). Research on adult learners: Supporting the needs of a student population that is no longer nontraditional. Peer Review, 13(1), 26-29.

Schneider, M., \& Somers, M. (2006). Organizations as complex adaptive systems: Implications of complexity theory for leadership research. The Leadership Quarterly, 17(4), 351-365.

Shoup, J. R. (2016). Leadership, Organizational, and Institutional Studies: Reconciling and Teaching Competing Perspectives. Journal of Leadership Education, 15(4).

Taylor, L. (2015, May). Can I do both? Be employed and graduate? Adult non-traditional learners who combine employment and higher education enrollment: A look at persistence and best practices to overcoming barriers to improve success and retention. Paper presented at the Adult Education Research Conference.

Uhl-Bien, M., \& Marion, R. (2009). Complexity leadership in bureaucratic forms of organizing: A meso model. The Leadership Quarterly, 20(4), 631-650.

Uhl-Bien, M., Marion, R., \& McKelvey, B. (2007). Complexity leadership theory: Shifting leadership from the industrial age to the knowledge era. The leadership quarterly, 18(4), 298-318.

Weberg, D. R. (2013). Complexity leadership theory and innovation: A new framework for innovation leadership (Doctoral dissertation, Arizona State University). 
Wendler, C., Bridgeman, B., Cline, F., Millett, C., Rock, J., Bell, N., \& McAllister, P. (2010). The Path Forward: The Future of Graduate Education in the United States. Educational Testing Service.

Yukl, G. (2009). Leading organizational learning: Reflections on theory and research. The Leadership Quarterly, 20(1), 49-53.

\section{Author Biographies}

Dr. Steven Winton is an Assistant Professor and Director of the MA Leadership and Organizational Development program at Saint Louis University. He holds a Ph.D.in Industrial/Organizational Psychology and is interested in the scholarship of leadership development, as well as employee engagement. Email: steven.winton@slu.edu

Sarah Palmer, M.S., is a graduate student in the Industrial-Organizational Psychology doctoral program at Saint Louis University. Her personal research focuses on organizational citizenship behavior, work-role boundaries, and organizational justice. She is currently an Associate Consultant at a consulting firm in the St. Louis area. Email: sarah.guarino@slu.edu

Dr. Patrick Hughes has a Ph.D.in Leadership from Alvernia University (2013). He also holds a M.S. in Organizational Development and Leadership from Shippensburg University (2006). He is the current Program Director/Assistant Professor of Justice Leadership and Management at the University of Baltimore. Email: phughes@ubalt.edu 